\title{
Reactions of $\left[\mathrm{NH}_{3}^{+*}, \mathrm{H}_{2} \mathrm{O}\right]$ with Carbonyl \\ Compounds: A McLafferty Rearrangement Within a Complex?
}

\author{
G. van der Rest, L. B. Jensen,* S. Abdel Azeim, P. Mourgues, \\ and H. E. Audier \\ Laboratoire des Mécanismes Réactionnels, CNRS, Ecole Polytechnique, Palaiseau, France
}

The reactions of the water solvated ammonia radical cation $\left[\mathrm{NH}_{3}^{+}, \mathrm{H}_{2} \mathrm{O}\right]$ with a variety of aldehydes and ketones were investigated. The reactions observed differ from those of low energy aldehydes and ketones radical cations, although electron transfer from the keto compound to ionized ammonia is thermodynamically allowed within the terbody complexes initially formed. The main process yields an ammonia solvated enol with loss of water and an alkene. This process corresponds formally to a McLafferty fragmentation within a complex. With aldehydes, another reaction can take place, namely the transfer of the hydrogen from the $\mathrm{CHO}$ group to ammonia, leading to the proton bound dimer of ammonia and water, and to the $\mathrm{NH}_{4}^{+}$cation. Comparison between the available experimental results leads to the conclusion that the McLafferty fragmentation occurs within the terbody complex initially formed, with no prior ligand exchange, the water molecule acting as a spectator partner. (J Am Soc Mass Spectrom 2004, 15, 966-971) (c 2004 American Society for Mass Spectrometry

$\mathrm{T}$ The study of the unimolecular and bimolecular reactivity of solvated radical cations requires access to such kind of species. Of course, by direct reactions between an ion and a solvent molecule in the cell of an ion cyclotron resonance mass spectrometer (FT-ICR), an encounter complex is formed in which reactions can take place. However, the solvated radical cations formed in this way possess a high energetic content (at least equal to the solvation energy) and are too short lived to be isolated and studied. Furthermore, since these species are hot ions, their fragmentations correspond to the unimolecular reactions which are entropically favored. Therefore, the reactions observed are not necessarily the same as those of long lived solvated radical cations, as demonstrated in the case of the $\mathrm{CH}_{2} \mathrm{CHOH}^{+} / \mathrm{CH}_{3} \mathrm{CHO}$ system [1], where the acetaldehyde solvated enol ion is produced by reaction of the enol ion with paraldehyde (eq 1). In this case, the hot intermediate reacts by $\mathrm{H}^{+}$transfer, whereas low energy collision induced dissociation of the solvated complex leads to $\mathrm{H}^{-}$abstraction [1].

$$
\begin{aligned}
& \mathrm{CH}_{2} \mathrm{CHOH}^{++}+\left(\mathrm{CH}_{3} \mathrm{CHO}\right)_{3} \\
\rightarrow & {\left[\mathrm{CH}_{2} \mathrm{CHOH}^{++}, \mathrm{CH}_{3} \mathrm{CHO}\right]+\left(\mathrm{CH}_{3} \mathrm{CHO}\right)_{2} }
\end{aligned}
$$

Published online June 15, 2004

This work is dedicated to Fred W. McLafferty, who brought to all of us so much in our field, and it is not over!

Address reprint requests to Dr. G. van der Rest, Laboratoire des Mécanismes Réactionnels, UMR 7651 CNRS, Ecole Polytechnique, 91-128 Palaiseau Cedex, France. E-mail: gvdr@dcmr.polytechnique.fr

*Present address: Department of Chemistry, The H. C. Ørsted Institute, University of Copenhagen, Copenhagen, Denmark.
A variety of methods have been described for the preparation of solvated radical cations [2-9]. Among them, the preparation of the water solvated ammonia radical cation has been recently described [3] by use of a specific ion molecule reaction between ionized formamide (or its carbene isomer) and water (eq 2).

$$
\mathrm{HCONH}_{2}{ }^{+}+\mathrm{H}_{2} \mathrm{O} \rightarrow\left[\mathrm{H}_{2} \mathrm{NH} . . \mathrm{OH}_{2}\right]^{+\cdot}+\mathrm{CO}
$$

The bimolecular reactions of the $\left[\mathrm{NH}_{3}^{+*}, \mathrm{H}_{2} \mathrm{O}\right]$ ion allow the preparation of new ammonia solvated species [3]. The dissymetric repartition of the charge facilitates the replacement of water by the neutral reactant, allowing the production of ions such as $\left[\mathrm{NH}_{3}, \mathrm{CS}_{2}\right]^{+},\left[\mathrm{NH}_{3}\right.$, $\left.\mathrm{C}_{6} \mathrm{H}_{6}\right]^{+}$, $\left[\mathrm{NH}_{3}, \mathrm{CH}_{3} \mathrm{OH}\right]^{+}$, etc. However, ligand exchange (with covalent bond formation or not) is not the only process observed, and other reactions such as electron transfer, or hydrogen atom abstraction (eq 3), can occur [10].

$$
\begin{gathered}
{\left[\mathrm{NH}_{3}{ }^{+\cdot}, \mathrm{H}_{2} \mathrm{O}\right]+\left(\mathrm{CH}_{3}\right)_{2} \mathrm{C}=\mathrm{CH}_{2}} \\
\rightarrow \mathrm{H}_{3} \mathrm{~N} \ldots \mathrm{H}^{+} \ldots \mathrm{OH}_{2}+\mathrm{C}_{4} \mathrm{H}_{7}{ }^{\circ}
\end{gathered}
$$

Among these other reactions, fragmentations can occur within the encounter complex formed between $\left[\mathrm{NH}_{3}^{+}\right.$, $\mathrm{H}_{2} \mathrm{O}$ and the neutral reactant. For instance, with tertbutyl alcohol, a $\left[\left(\mathrm{CH}_{3}\right)_{2} \mathrm{C}-\mathrm{O} . . . \mathrm{H}^{+} \ldots \mathrm{NH}_{3}\right]$ product is formed and a methyl radical and water are eliminated (eq 4) [10]. 
Table 1. Products of the reactions of the ion with different aldehydes and ketones (pressure $=1-410^{-8}$ mbar, reaction time $=4-8$ seconds

\begin{tabular}{lcccc}
\hline Neutral reactant & Enol, $\mathrm{NH}_{3}{ }^{+}$ & $\mathrm{NOH}_{6}{ }^{+}$ & $\mathrm{NH}_{4}^{+}$ & Electron transfer \\
\hline \hline $\mathrm{CH}_{3}\left(\mathrm{CH}_{2}\right)_{2} \mathrm{CHO}$ & +++ & + & ++ & - \\
$\mathrm{CH}_{3}\left(\mathrm{CH}_{2}\right)_{4} \mathrm{CHO}$ & +++ & + & +++ & - \\
$\mathrm{CH}_{3} \mathrm{CH}\left(\mathrm{CH}_{3}\right) \mathrm{CH}_{2} \mathrm{CHO}$ & +++ & - & + & - \\
$\mathrm{CH}_{3} \mathrm{CH}_{2} \mathrm{C}\left(\mathrm{CH}_{3}\right) \mathrm{CH}_{2} \mathrm{CHO}$ & + & +++ & ++ & - \\
$\left(\mathrm{CH}_{3}\right)_{3} \mathrm{CCH}_{2} \mathrm{CHO}$ & +++ & - & + & - \\
$\mathrm{CH}_{3} \mathrm{CO}\left(\mathrm{CH}_{2}\right)_{2} \mathrm{CH}_{3}$ & ++ & - & + & ++ \\
$\mathrm{CH}_{3} \mathrm{CO}\left(\mathrm{CH}_{2}\right)_{3} \mathrm{CH}_{3}$ & +++ & - & + & ++ \\
$\mathrm{CH}_{3} \mathrm{CO}\left(\mathrm{CH}_{2}\right)_{4} \mathrm{CH}_{3}$ & +++ & - & + & ++ \\
$\left.\mathrm{CH}_{3} \mathrm{COCH} \mathrm{CH}_{2} \mathrm{CH}_{3}\right)_{2}$ & ++ & - & + & ++ \\
$\mathrm{CH}_{3} \mathrm{COC}\left(\mathrm{CH}_{3}\right)_{3}$ & - & - & - & +++ \\
$\mathrm{CH}_{3} \mathrm{CH}_{2} \mathrm{CO}\left(\mathrm{CH}_{2}\right)_{3} \mathrm{CH}_{3}$ & ++ & - & \\
\hline
\end{tabular}

+++ : dominant peak; ++ : important peak; +: minor peak; -: not observed

asome loss of $\mathrm{C}_{4} \mathrm{H}_{9}$ radical is also observed.

$$
\begin{aligned}
& {\left[\mathrm{NH}_{3}{ }^{+\cdot}, \mathrm{H}_{2} \mathrm{O}\right]+\left(\mathrm{CH}_{3}\right)_{3} \mathrm{COH} \rightarrow} \\
& {\left[\left(\mathrm{CH}_{3}\right)_{2} \mathrm{C}=\mathrm{O} \ldots \mathrm{H}^{+} \ldots \mathrm{NH}_{3}\right]+\mathrm{CH}_{3}{ }^{\cdot}+\mathrm{H}_{2} \mathrm{O}}
\end{aligned}
$$

Other fragmentation reactions are also observed when $\left[\mathrm{NH}_{3}^{+}, \mathrm{H}_{2} \mathrm{O}\right]$ reacts with aldehydes and ketones, and this is the subject of this work. The reaction most frequently observed involves the elimination of both water and an alkene, giving as main product an ammonia solvated enol. It will be shown that the formation of these complexes corresponds, at least formally, to a McLafferty fragmentation within the complex.

\section{Experimental}

\section{FT-ICR Experiments}

Experiments were performed with a Bruker CMS-47X FT-ICR mass spectrometer (Fällanden, Switzerland) equipped with an external ion source [11] and an Infinity cell $[12,13]$. The neutral reactants were introduced into the cell through a leak valve at a pressure of $1 \times 10^{-8}$ to $4 \times 10^{-8} \mathrm{mbar}$ (depending on the experiment) and then diluted with water to give a total pressure of $2-3 \times 10^{-7} \mathrm{mbar}$. When appropriate, other neutral reactants were introduced by means of a solenoid pulsed valve.

The $\left[\mathrm{NH}_{3}^{+}, \mathrm{H}_{2} \mathrm{O}\right]$ ion was generated in the cell by reaction with water of ionized aminohydroxycarbene $\mathrm{HOCNH}_{2}^{+} m / z 45$, produced in the external source by electron ionization of oxamide [3]. After transfer into the cell, the ion $m / z 45$ was allowed to react $1.5 \mathrm{~s}$ with water, then $\left[\mathrm{NH}_{3}^{+}, \mathrm{H}_{2} \mathrm{O}\right] \mathrm{m} / z 35$ was isolated by applying low-voltage single radio frequency (rf) pulses (soft shots) at the resonance frequencies of all unwanted ions.

Low energy collision induced dissociation (CID) of ions was performed by applying an on-resonance $\mathrm{rf}$ pulse (typically 60 to $120 \mu$ s irradiation time, $\mathrm{V}_{p-p}=18$ $\mathrm{V})$, and allowing the excited ions to collide 50-100 ms with the water bath $\left(2.10^{-7}\right.$ mbar $)$. The kinetic energy in the center of mass of the system was calculated taking
0.90 as the geometric factor for the Infinity cell [13], and was typically in the $10-60 \mathrm{eV}$ range.

Metastable ions kinetic energy (MIKE) spectra were recorded in Copenhagen on a Jeol JMS-HX/HX110A four-sector double-focusing mass spectrometer (EBEB geometry) in three-sector mode under standard operating conditions.

\section{Reactants}

Compounds were purchased commercially (Aldrich, San Quentin, France). The $\left[\mathrm{ND}_{3}^{+\cdot}, \mathrm{D}_{2} \mathrm{O}\right]$ has been generated in the cell by reaction of $\mathrm{D}_{2} \mathrm{O}$ with $\mathrm{DOCND}_{2}^{-+}$, itself formed by fragmentation of $\mathrm{N}-d_{4}$ oxamide.

\section{Calculations}

The various structures of entry and exit points were computed by $a b$ initio molecular orbital calculations performed at the $\mathrm{MP} 2 / 6-31 \mathrm{G}^{* *}$ level of the theory, using the Gaussian 98 [14] program suite. For each structure, the Hessian of the potential energy surface was computed at the same level of the theory so as to check that they corresponded to minima on the potential energy surface and in order to derive thermochemical values.

\section{Results}

Reactions of $\left[\mathrm{NH}_{3}^{+*}, \mathrm{H}_{2} \mathrm{O}\right]$ with several aliphatic aldehydes and ketones (Table 1) were performed. In all cases where an hydrogen is present in a $\gamma$-position to the carbonyl group, a product corresponding formally to an ionized enol solvated by $\mathrm{NH}_{3}$ is abundant (Figure 1 ). The enol moiety is the same as the ionized enol which is formed by a McLafferty rearrangement in the corresponding ionized aldehyde or ketone at high internal energy (eqs 5-8). In short chained aldehydes or ketones with no $\gamma-\mathrm{H}$, this product is not observed.

$$
\mathrm{CH}_{3}\left(\mathrm{CH}_{2}\right)_{2} \mathrm{CHO}^{+\cdot} \rightarrow \mathrm{CH}_{2}=\mathrm{CHOH}^{+\bullet}+\mathrm{C}_{2} \mathrm{H}_{4}
$$



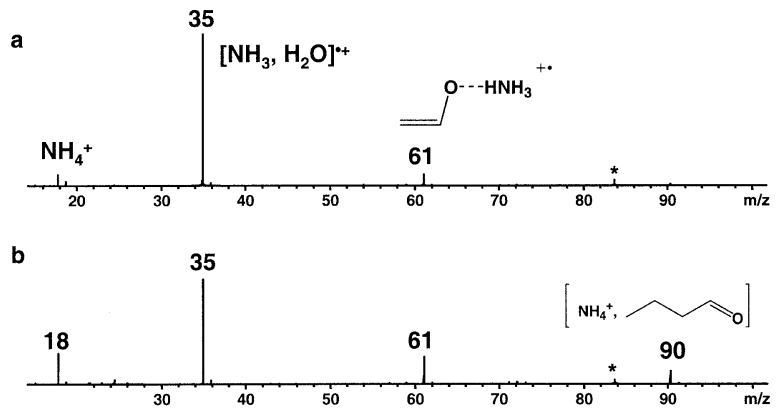

Figure 1. Reaction of $\left[\mathrm{NH}_{3}^{-+}, \mathrm{H}_{2} \mathrm{O}\right]$ with butanal $\left(3 \times 10^{-8}\right.$ mbar $)$. (a) Reaction time $2 \mathrm{~s}$; (b) Reaction time $4 \mathrm{~s}$. Spurious frequency at $\mathrm{m} / \mathrm{z} 83.5$, inherent to the equipment.

$$
\begin{aligned}
& \mathrm{CH}_{3}\left(\mathrm{CH}_{2}\right)_{4} \mathrm{CHO}^{+\cdot} \rightarrow \mathrm{CH}_{2}=\mathrm{CHOH}^{+\bullet}+\mathrm{C}_{4} \mathrm{H}_{8} \\
& \mathrm{CH}_{3} \mathrm{CO}\left(\mathrm{CH}_{2}\right)_{2} \mathrm{CH}_{3}^{+\cdot} \rightarrow \mathrm{CH}_{3} \mathrm{C}(\mathrm{OH})=\mathrm{CH}_{2}^{+\bullet}+\mathrm{C}_{2} \mathrm{H}_{4}
\end{aligned}
$$

$$
\begin{aligned}
& \mathrm{CH}_{3} \mathrm{CH}_{2} \mathrm{CO}\left(\mathrm{CH}_{2}\right)_{3} \mathrm{CH}_{3}^{+\cdot} \rightarrow \\
& \mathrm{CH}_{3} \mathrm{CH}_{2} \mathrm{C}(\mathrm{OH})=\mathrm{CH}_{2}^{+\cdot}+\mathrm{C}_{3} \mathrm{H}_{6}
\end{aligned}
$$

However, when the McLafferty fragmentation of the free ionized carbonyl compound (for instance 3,3-dimethyl butanal) produces both an ionized alkene and an enol radical cation in competition, the terbody encounter complex gives only the ammonia solvated enol radical cation. No complex between ammonia an ionized alkene is observed (eqs 9 and 10).

$$
\begin{aligned}
& \left(\mathrm{CH}_{3}\right)_{3} \mathrm{CCH}_{2} \mathrm{CHO}^{+\cdot} \\
& \rightarrow\left(\mathrm{CH}_{3}\right)_{2} \mathrm{C}=\mathrm{CH}_{2}{ }^{+\cdot}+\mathrm{CH}_{2}=\mathrm{CHOH} \\
& \rightarrow\left(\mathrm{CH}_{3}\right)_{2} \mathrm{C}=\mathrm{CH}_{2}+\mathrm{CH}_{2}=\mathrm{CHOH}^{+} \cdot \\
& \left(\mathrm{CH}_{3}\right)_{3} \mathrm{CCH}_{2} \mathrm{CHO}+\left[\mathrm{NH}_{3}^{+\cdot}, \mathrm{H}_{2} \mathrm{O}\right] \\
& \rightarrow\left[\mathrm{CH}_{2}=\mathrm{CHOH}, \mathrm{NH}_{3}\right]^{+\cdot}
\end{aligned}
$$

With aldehydes, the $\mathrm{NH}_{4}^{+}$cation is often formed, along with, in some cases, the $\mathrm{H}_{3} \mathrm{~N} . . \mathrm{H}^{+} \ldots \mathrm{OH}_{2}$ proton bound dimer. With ketones, $\mathrm{NH}_{4}^{+}$formation is not observed, or only as a minor process.

With ketones, a direct electron transfer (ET) is often important, if not dominant, especially when the ionization energy of the keto compound is lower than $9.3 \mathrm{eV}$.
It has been difficult to measure the rate constants since several compounds are present in the cell where the $\left[\mathrm{NH}_{3}^{+*}, \mathrm{H}_{2} \mathrm{O}\right]$ is generated (see experimental). However, it can be roughly evaluated that the reactions leading to the ammonia solvated enol are slow, significantly less that one tenth of the collision rate.

\section{Structure of the McLafferty Product}

Upon collision, the ammonia solvated enol ions only yield $\mathrm{NH}_{4}^{+}$as fragment. Furthermore, their further ligand exchange reactions with the keto-compounds $\mathrm{M}$ in the cell, leads to $\left[\mathrm{M}, \mathrm{NH}_{4}^{+}\right]$products. These observations are in agreement with the known relative proton affinities of the $\mathrm{CH}_{2}=\mathrm{CHO}^{\circ}$ and $\mathrm{CH}_{2}=\mathrm{C}\left(\mathrm{CH}_{3}\right) \mathrm{O}^{\circ}$ radicals [15] on the one hand and of ammonia [16] on the other, and they strongly suggest that the ammonia solvated $\mathrm{CH}_{2}=\mathrm{CHOH}^{+\cdot}$ and $\mathrm{CH}_{2}=\mathrm{C}\left(\mathrm{CH}_{3}\right) \mathrm{OH}^{+\cdot}$ ions possess the $\left[\mathrm{CH}_{2}=\mathrm{CHO}, \mathrm{NH}_{4}^{+}\right]$and $\left[\mathrm{CH}_{2}=\mathrm{C}\left(\mathrm{CH}_{3}\right) \mathrm{O}^{\circ}\right.$, $\left.\mathrm{NH}_{4}^{+}\right]$structures. This is confirmed by the most stable calculated structure of the $\left[\mathrm{CH}_{2}=\mathrm{CHOH}, \mathrm{NH}_{3}\right]^{+\cdot}$ complex (Figure 2).

\section{Deuterium Labeling Experiments}

Labeling indicates that the $\alpha$-hydrogens of the ketone are not involved in $\mathrm{H}$-transfer or $\mathrm{H}$-exchange processes. For instance, the $\left(1,1,1,3,3-d_{5}\right)$-2-heptanone yields a $\left[\mathrm{CD}_{2}=\mathrm{C}\left(\mathrm{CD}_{3}\right) \mathrm{O}, \mathrm{NH}_{4}^{+}\right]$product giving pure $\mathrm{NH}_{4}^{+}$upon $\mathrm{CID}$, and no D-abstraction is observed (no $\mathrm{NDH}_{3}^{+}$).

Reaction of $\left[\mathrm{ND}_{3}^{+\cdot}, \mathrm{D}_{2} \mathrm{O}\right]$ with butanal or with 2-hexanone, yields $\left[\mathrm{CH}_{2}=\mathrm{CHO}, \mathrm{NHD}_{3}^{+}\right]$and $\left[\mathrm{CH}_{2}=\mathrm{C}\left(\mathrm{CH}_{3}\right) \mathrm{O}^{\circ}\right.$, $\mathrm{NHD}_{3}^{+}$] respectively, as shown by $\mathrm{CID}$ experiments. These results prove clearly that the $\gamma$-hydrogen transferred, as required by the McLafferty fragmentation, is retained in the product ion, and does not end up on the oxygen of water nor undergoes $H / D$ exchange with the water molecule.

\section{Ejection of Putative Intermediate Complexes}

The formation of the ammonia solvated enol ion requires the elimination of water and of an alkene. None of the putative intermediates, i.e., $\left[\mathrm{M}, \mathrm{NH}_{3}\right]^{++}$and [enol, $\left.\mathrm{NH}_{3}, \mathrm{H}_{2} \mathrm{O}\right]^{++}$, are observed in the ICR cell. Nevertheless, provided that their lifetime is sufficient, a fast continuous ejection of one of the possible intermediates, if it is involved, would influence the amount of the final product [enol, $\left.\mathrm{NH}_{3}\right]^{++}$. Such experiments have been
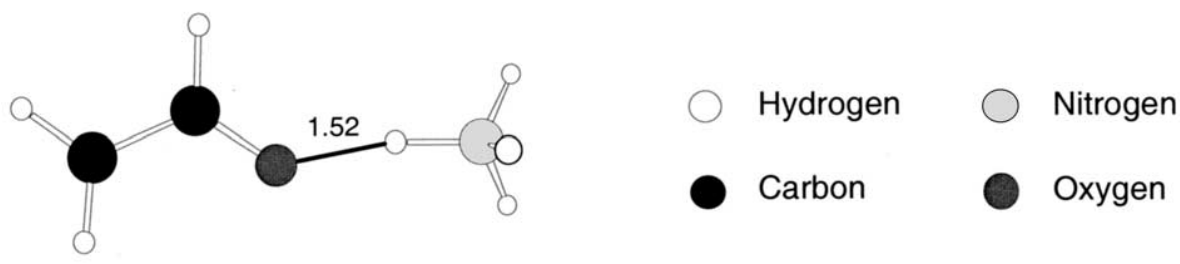

Figure 2. Most stable geometry calculated for the $\left[\mathrm{CH}_{2}=\mathrm{CHOH}, \mathrm{NH}_{3}\right]^{-+}$product ion. 
performed, varying the ejection time from 50 to $150 \mu \mathrm{s}$ [17]. Unfortunately, no definitive conclusion could be drawn from these attempts, because even when some decrease of the final ion was observed (for high irradiating voltages, i.e., short ejection times), the same result was obtained by a similar irradiation either off-resonance or symmetrically on the high frequency side (i.e., at $\nu+\Delta \nu$ instead of $\nu-\Delta \nu$ ). In other words, the decrease in intensity observed comes from off resonance effects, and not from the fast ejection of any intermediate.

\section{Discussion}

The mechanism of formation of the ammonia solvated enol will first be discussed. This formation involves several steps: Water elimination, direct or indirect $\mathrm{H}$ transfer to the carbonyl group, cleavage of a $\mathrm{C}-\mathrm{C}$ bond leading to alkene loss. However, nothing is known a priori about the ordering of the different steps.

\section{Are Ionized Aldehydes or Ketones Formed by ET Within a Complex?}

The reactions observed within the terbody complex [M, $\left.\mathrm{NH}_{3}, \mathrm{H}_{2} \mathrm{O}\right]^{++}$could be expected to involve decomposition of low energy $\mathrm{M}^{+}$, at least when the electron transfer between $\mathrm{M}$ and $\mathrm{NH}_{3}^{+}$(where the charge is originally localized) is exothermic. This is indeed the case for all the carbonyl compounds studied here, if we compare the IE of ammonia $(10.07 \mathrm{eV})$ with for instance butanal $(9.82 \mathrm{eV})$, the compound of highest EI in our study.

For that reason, it is worth comparing our results with the unimolecular reactions of metastable $\mathrm{M}^{+}$, as described in the literature [18]. A striking difference is that the fragmentations of metastable $\mathrm{M}^{++}$, especially alkyl losses, do not occur within the $\left[\mathrm{M}, \mathrm{NH}_{3}, \mathrm{H}_{2} \mathrm{O}\right]^{++}$ complexes. Conversely, the McLafferty fragmentation (accompanied by loss of water) is the main reaction observed within the $\left[\mathrm{M}, \mathrm{NH}_{3}, \mathrm{H}_{2} \mathrm{O}\right]^{++}$complexes, provided that an hydrogen exist in the $\gamma$ position of the carbonyl group of $\mathrm{M}$. This fragmentation is rarely observed as a significant reaction in the MIKE spectrum of the carbonyl compounds studied here.

For instance, the dissociation of metastable ionized butanal is dominated by losses of methyl and ethyl radicals, both reactions being totally absent in the reaction of the terbody complex (Figure 1). Similarly, metastable ionized 2-hexanone loses almost exclusively a methyl group, which is not observed in our experiment. As a further example, 3,3-dimethylbutanal reacts with $\left[\mathrm{NH}_{3}, \mathrm{H}_{2} \mathrm{O}\right]^{+}$to give $\left[\mathrm{CH}_{2}=\mathrm{CHO}, \mathrm{NH}_{4}^{+}\right]$in a very high yield, whereas its MIKE spectrum is dominated by the loss of ethylene (this work), with no McLafferty fragmentation.

This comparison shows that the mechanism of formation of the ammonia solvated enol ion is more intricate than a simple charge transfer mechanism, where the water and ammonia molecules would act only as spectator partners within the reaction complex. The lack of evidence for an [enol, $\left.\mathrm{NH}_{3}, \mathrm{H}_{2} \mathrm{O}\right]^{\cdot+}$ intermediate complex (see the Results section) is in line with this conclusion.

\section{[Aldehyde ${ }^{+}, \mathrm{NH}_{3}$ ] or $\left[\right.$ Ketone $^{+*}, \mathrm{NH}_{3}$ ] are Not Intermediate Complexes}

Another possible mechanism could be a ligand exchange reaction, leading to the substitution of a water molecule by the neutral reactant, followed by an ET reaction between ionized ammonia and the neutral, and subsequent fragmentation. But this hypothesis can be ruled out according to the following results:

It has been shown previously that ligand switching between water and the neutral reactant is generally easy for the bimolecular reactions of $\left[\mathrm{NH}_{3}^{+}, \mathrm{H}_{2} \mathrm{O}\right]$ [3]. In this study, as already pointed out, the complexes [Aldehyde, $\left.\mathrm{NH}_{3}\right]^{+\cdot}$ or [Ketone, $\mathrm{NH}_{3}{ }^{+\cdot}$ do not exist unless they have a very short lifetime, which is unlikely considering previously known results [3] and the fact that with carbonyl compound the reaction is slow.

Another argument against an initial ligand switching comes from the reactions of ionized aldehydes and ketones with ammonia, which are currently under study. First results indicate that different processes are observed (isomerization of the ion, protonation of ammonia, etc.) [19], at a very low rate, but in all cases the abundance of the fragment corresponding to an ammonia solvated enol is negligible. This clearly indicates that the hypothesis of a ligand exchange as a first step is not likely.

These results strongly suggest that the water molecule is therefore involved, at least in the first steps of the McLafferty fragmentation.

\section{Labeled Compound Studies: Water as Spectator}

The reactions of $\left[\mathrm{ND}_{3}^{+*}, \mathrm{D}_{2} \mathrm{O}\right]$ reported above show, however, that the water molecule is not involved in any H-transfer originating from the keto compound, nor any $H / D$ exchange with the departing fragments. Therefore, if the presence of water is necessary for the McLafferty reaction to occur, it is only as a spectator molecule, which is not active in the $\mathrm{H}$ transfer process itself.

\section{Aldehydes: Competing Reaction Pathways}

In the case of the aldehydes, in addition to the McLafferty fragmentation pathway described previously, a competing $\mathrm{H}^{*}$ abstraction pathway is observed experimentally, leading to either the water ammonia proton bound dimer or to protonated ammonia. Since this process is important in the case of aldehydes and not for 
Table 2. $\Delta \mathrm{E}_{298}$ for the different reactions of $\left[\mathrm{NH}_{3}, \mathrm{H}_{2} \mathrm{O}\right]^{++}$with butanal (energies in $\mathrm{kcal} \mathrm{mol}^{-1}$ )

\begin{tabular}{lcr}
\hline Species & $\mathrm{E}\left(\mathrm{MP} 2 / 6-31 \mathrm{G}^{* *}\right)$ & \multicolumn{1}{c}{$\Delta \mathrm{E}_{298}$} \\
\hline \hline$\left[\mathrm{NH}_{3}, \mathrm{H}_{2} \mathrm{O}\right]^{++}+\mathrm{CH}_{3} \mathrm{CH}_{2} \mathrm{CH}_{2} \mathrm{CHO}$ & 0.0 & -0.0 \\
{$\left[\mathrm{NH}_{4}^{+}, \mathrm{H}_{2} \mathrm{O}\right]+\mathrm{CH}_{3} \mathrm{CH}_{2} \mathrm{CH}_{2} \mathrm{CO}$} & -34.0 & -30.9 \\
$\mathrm{CH}_{2} \mathrm{CHO} \mathrm{HNH}_{4}^{+}+\mathrm{C}_{2} \mathrm{H}_{4}+\mathrm{H}_{2} \mathrm{O}$ & 5.2 & 3.6 \\
$\mathrm{NH}_{4}^{+}+\mathrm{CH}_{3} \mathrm{CH}_{2} \mathrm{CH}_{2} \mathrm{CO}+\mathrm{H}_{2} \mathrm{O}$ & -9.8 & -8.5 \\
$\mathrm{CH}_{3} \mathrm{CH}_{2} \mathrm{CH}_{2} \mathrm{CO} \ldots \mathrm{NH}_{4}^{+}+\mathrm{H}_{2} \mathrm{O}$ & -30.8 & -27.9 \\
$\mathrm{NH}_{4}^{+}+\mathrm{CH}_{2} \mathrm{CHO}^{+}+\mathrm{C}_{2} \mathrm{H}_{4}+\mathrm{H}_{2} \mathrm{O}$ & 35.6 & 32.4 \\
\hline
\end{tabular}

ketones, this suggests that the aldehydic hydrogen is transferred.

$\mathrm{Ab}$ initio calculations were led in order to rank the relative energies and free enthalpies of the different possible exit points for butanal and for 3,3-dimethylbutanal (Tables 2 and 3). These results show that the abstraction of the hydrogen is a very exothermic pathway: The formation of the $\left[\mathrm{NH}_{4}^{+}, \mathrm{H}_{2} \mathrm{O}\right]$ dimer leads to an exit point $30.9 \mathrm{kcal} \mathrm{mol}^{-1}$ more stable than the entry point. In fact, the internal energy of this fragmentation ion is most probably sufficient to lead to near complete dissociation of the ammonia water protonated dimer. By contrast, the solvated McLafferty fragmentation leads to reaction products which are at the level or slightly above the entry point.

On the other hand, the McLafferty-type fragmentation products are located close to the entry point, within the thermal energy of the ions (about $2 \mathrm{kcal} \mathrm{mol}^{-1}$ ) and the theoretical calculation margin of error (also about 2 $\mathrm{kcal} \mathrm{mol}^{-1}$ ). This is in agreement with the slow rate of formation of the ammonia solvated ion (less then one tenth of the collision rate). The question is therefore: Why are the McLafferty-type products observed in abundance similar or higher than that of the energetically more favored formation of $\left[\mathrm{NH}_{4}^{+}, \mathrm{H}_{2} \mathrm{O}\right]$ or $\mathrm{NH}_{4}^{+}$?

A detailed study of the potential energy surface for this system is currently under way and will provide more information on these competing pathways. But this experimental difference in reactivity already leads to some insights on the reaction channel: A high energy barrier, at least close to the competing fragmentation product, must be present somewhere on the pathway leading to transfer of the - $\mathrm{CHO}$ hydrogen to ammonia; otherwise it would be the only reaction channel observed.

Previous theoretical work from our group has shown that a proton transfer from ionized acetaldehyde to different bases is very easy and occurs without any significant barrier [20]. Since ammonia is a stronger base than those considered in these studies, a transfer from the ionized aldehyde to the ammonia moiety within a three-body complex with the charge located on the aldehyde should take place with a negligible barrier. Further fragmentation of the three-body complex leads easily to the protonated ammonia products. These arguments indicate that the critical step is prior to the localization of the charge on the aldehyde moiety in an intermediate three-body complex. It could well be that the critical step is the transfer of the electron from ammonia to the aldehyde molecule. One could speculate that, as in the $\left[\mathrm{NH}_{3}, \mathrm{H}_{2} \mathrm{O}\right]^{+}$complex, the water molecule continues to stabilize the charge on the ammonia moiety throughout the reaction. Another hypothesis could also be that a barrier prevents a reorganization of one intermediate three-body complex into a complex in which the ammonia moiety is located close to the $-\mathrm{CHO}$ hydrogen. As already stated, ab initio calculations are currently carried out in order to clear these points.

\section{Competition Between Alkene and Enol Elimination: The Case of 3,3-Dimethylbutanal}

Despite the formation of an ionized isobutene fragment in the unimolecular reaction of the 3,3-dimethylbutanal (eq 9), no product (covalent or not) corresponding to an ammonia solvated isobutene is observed when this aldehyde is allowed to react with $\left[\mathrm{NH}_{3}^{+}, \mathrm{H}_{2} \mathrm{O}\right]$. Calculations of the different possible final states were carried out. Table 3 indicates that all the product ions containing the isobutene moiety lie, in energy, much too high to be formed. The three possible reactions are those experimentally observed (Table 1, Table 3 ).

\section{Conclusion}

Reactions of $\left[\mathrm{NH}_{3}^{+\cdot}, \mathrm{H}_{2} \mathrm{O}\right]$ with aldehydes and ketones give a new and easy method for preparing ammonia solvated enols in the gas phase. In an H-bonded complex between the carbonyl group and the charged ammonia moiety, a $\gamma$-hydrogen is transferred, followed by losses of water and of alkene. This mimics the

Table 3. $\Delta \mathrm{E}_{298>}$ for the different reactions of $\left[\mathrm{NH}_{3}, \mathrm{H}_{2} \mathrm{O}\right]^{++}$with 3,3-dimethylbutanal (energies in kcal mol ${ }^{-1}$ )

\begin{tabular}{|c|c|c|}
\hline Species & $\mathrm{E}(\mathrm{MP} 2 / 6-31 \mathrm{G} * *)$ & $\Delta \mathrm{E}_{298}$ \\
\hline$\left[\mathrm{NH}_{3}, \mathrm{H}_{2} \mathrm{O}\right]^{++} \mathrm{tBuCH}_{2} \mathrm{CHO}$ & 0.0 & -0.0 \\
\hline$\left[\mathrm{NH}_{4}^{+}, \mathrm{H}_{2} \mathrm{O}\right]+\mathrm{tBuCH}_{2} \mathrm{CO}$ & -35.2 & -32.6 \\
\hline $\mathrm{CH}_{2} \mathrm{CHO} \ldots \mathrm{NH}_{4}^{+}+$Isobutene $+\mathrm{H}_{2} \mathrm{O}$ & 1.4 & 0.3 \\
\hline $\mathrm{NH}_{4}^{+}+\mathrm{tBuCH}_{2} \mathrm{CO}+\mathrm{H}_{2} \mathrm{O}$ & -11.0 & -10.1 \\
\hline Isobutene ${ }^{+}+\mathrm{CH}_{2}=\mathrm{CHOH}+\mathrm{NH}_{3}+\mathrm{H}_{2}$ ) & 54.8 & 49.6 \\
\hline $\mathrm{CH}_{3} \mathrm{CHCH}\left(\mathrm{NH}_{3}^{+}\right) \mathrm{CH}_{3}+\mathrm{CH}_{2} \mathrm{CHOH}+\mathrm{H}_{2} \mathrm{O}$ & 11.4 & 11.5 \\
\hline$\left[\mathrm{NH}_{4}^{+}, \mathrm{H}_{2} \mathrm{O}\right]+\mathrm{CH}_{3} \mathrm{CH}=\mathrm{CHCH}_{2} \cdot(\mathrm{Z})+\mathrm{CH}_{2}=\mathrm{CHOH}$ & 16.7 & 15.8 \\
\hline $\mathrm{NH}_{4}^{+}+\mathrm{CH}_{2}=\mathrm{CHO}^{-}+\mathrm{H}_{2} \mathrm{O}+$ isobutene & 31.8 & 29.1 \\
\hline
\end{tabular}


McLafferty fragmentation, observed in the corresponding high energy free radical cations of aldehydes and ketones. In this reaction, the solvating water molecule does not undergo an initial ligand switching, and acts as a spectator partner. However, further work is necessary to bring more light on the reaction mechanism, and calculations on the terbody complexes are under way.

Interestingly, last but not least, half a century after the famous work of Fred, the McLafferty fragmentation is always an excellent model to study new phenomena [21].

\section{References}

1. van der Rest, G.; Mourgues, P.; Nedev, H.; Audier, H. E. J. Am. Soc. Mass Spectrom. 2000, 11, 705-710.

2. (a) Terlouw, J. K.; Heerma, W.; Burgers, P. C.; Holmes, J. L. Can. J. Chem. 1984, 62, 289. (b) Postma, R.; van Helden, S. P.; van Lenthe, J. H.; Ruttink, P. J. A.; Terlouw, J. K.; Holmes, J. L. Org. Mass Spectrom. 1988, 23, 503.

3. van der Rest, G.; Mourgues, P.; Nedev, H.; Audier, H. E. J. Am. Chem. Soc. 2002, 124, 5561-5569.

4. Martrenchard, S.; Dedonder-Lardeux, C.; Jouvet, C.; Rockland, U.; Solgadi, D. J. Phys. Chem. 1995, 99, 13716.

5. Freriks, I. L.; de Koning, L. J.; Nibbering, N. M. M. J. Org. Chem. 1992, 57, 5976.

6. (a) Brutschy, B. J. Phys. Chem. 1990, 94, 8637. (b) Brutschy, B.; Eggert, J.; James, C.; Baumgärtel, H. J. Phys. Chem. 1991, 95, 5041. (c) Riehn, C.; Lahmann, C.; Brutschy, B. J. Phys. Chem. 1992, 96, 3626.
7. Troude, V.; van der Rest, G.; Mourgues, P.; Audier, H. E. J. Am. Chem. Soc. 1997, 119, 9287.

8. Tu, Y.; Holmes, J. L. J. Am. Chem. Soc. 2000, 122, 3695.

9. de Visser, S. P.; de Koning, L. J.; Nibbering, N. M. M. J. Am. Chem. Soc. 1998, 120, 1517.

10. van der Rest, G.; Jensen, L. B.; Mourgues, P.; Audier, H., unpublished.

11. Kofel, P.; Allemann, M.; Kellerhals, H. P.; Wanczek, K. P. Int. J. Mass Spectrom. Ion Processes 1985, 65, 97.

12. Caravatti, P., Allemann, M. Org. Mass Spectrom. 1991, 26, 514

13. Sievers, H. L.; Grützmacher, H. F.; Caravatti, P. Int. J. Mass Spectrom. Ion Processes 1996, 157/158, 283.

14. Frisch, M. J.; Trucks, G. W.; Schegel, H. B.; Scuseria, G. E., et al. Gaussian 98, Revision A.6; Gaussian Inc.: Pittsburgh, PA, 1998.

15. Bouchoux, G.; Chamot-Rooke, J.; Leblanc, D.; Mourgues, P.; Sablier, M. ChemPhysChem. 2001, 4, 235-241.

16. Hunter, E.; Lias, S. G. J. Chem. Phys. Ref. Data 1998, 27, 413.

17. Audier, H. E.; McMahon, T. B. J. Am. Chem. Soc. 1994, 116, 8294-8299.

18. Bouchoux, G. Mass Spectrom Rev. 1988, 7; 1-39; ibid 203-255.

19. van der Rest, G.; Jensen, L. B.; Mourgues, P.; Audier, H. E., unpublished.

20. van der Rest, G.; Nedev, H.; Chamot-Rooke, J.; Mourgues, P.; McMahon, T. B.; Audier, H. E. Int. J. Mass Spectrom. 2000, 202, 161-174.

21. McLafferty, F. W.; Turecek, F. Interpretation of Mass Spectra, 4th ed.; University Science Books: Mill Valey, CA, 1993, pp $1-371$. 